\title{
The Factors Associated with Mothers' Preventive Measures Against Home Accidents: A Descriptive Study from Istanbul, Turkey
}

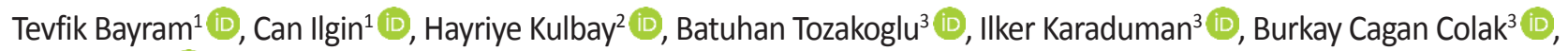 \\ Dilsad Save ${ }^{4}$ (D) \\ ${ }^{1}$ Marmara University, School of Medicine, Department of Public Health, Istanbul, Turkey \\ ${ }^{2}$ Zumrutevler Family Health Center-1, Istanbul, Turkey \\ ${ }^{3}$ Marmara University, School of Medicine, Istanbul, Turkey
}

Correspondence Author: Tevfik Bayram

E-mail: bayramtt@gmail.com

Received: $22.03 .2018 \quad$ Accepted: 13.06 .2018

\begin{abstract}
Objective: One of the most common causes of death among children in Turkey is accidents, and of this, 18-25\% caused by home accidents. This study aims to identify the factors associated with safety measures against home accidents, that are taken by mothers who have children between $0-6$ years of age.

Methods: This descriptive study was conducted among the mothers who admitted to three Family Health Centers in Istanbul, Turkey, in 2017. The data was collected with a questionnaire including "The Scale for Mother's identification of Safety Measures Against Home Accidents for Children of 0-6 Years Age Group". The data was analyzed with SPSS program using Chi square, Mann Whitney-U and Spearman correlation tests ( $p<0,05$ considered significant). 224 mothers participated in this study.

Results: The most frequent home accidents were falling (48.9\%), finger jam (36.6\%) and crashing (30.6\%). There was a weak positive correlation between the scale score and family's income ( $p=0.039 ; r=0.157)$; and a weak negative correlation between the scale score and child's age ( $p=0.001$; $r=-0.331$ ). There was no association between education level of parents and safety measures. However, the scale scores were significantly higher among those who have specifically been educated about home accidents compared to those who haven't $(\mathrm{p}=0.013)$.

Conclusion: The current education program may not be sufficient to prevent home accidents. We believe that specific courses about home accidents and safety measures are needed; even if these courses can be integrated to secondary school or university curricula it can be more beneficial.

Keywords: Turkey, home accidents, preventive measures, health education
\end{abstract}

\section{INTRODUCTION}

The accidents are the fourth most common cause of mortality among children in Turkey $(1,2)$. Nearly a quarter of all accidents are home accidents (3). The consequences of unintentional injuries are more severe especially in children who are younger than five years. The rates of hospital admission and mortality are high compared to other age groups (4). The impacts of home accidents on children's lives are long standing, which may cause physical, psychological and social impairments and thus affect the social interactions, academic life and future occupation of the kids $(4,5)$.

Home accidents cause a considerable financial burden in economy and health systems, which might affect the poor countries in higher magnitudes. Home accidents have the second largest share of economic burden caused by accidents (6) and, the rates of home accident and their consequences are higher in families and countries with lower socio-economic status $(7,8)$. Because of the complex nature of home accidents, more research needed to be done to understand and prevent home accidents. Therefore, in this study we aimed to find the factors associated with safety measures of mothers with children aged 0-6 years against home accidents. We have chosen mothers as the study population because of the fact that mothers are generally the primary caregivers of children.

\section{METHODS}

This descriptive study was conducted among the mothers who admitted to three Family Health Centers (FHC), in Istanbul, Turkey, in 2017. Three different FHCs were chosen to cover neighborhoods from different socio-economic statuses. From a non-probabilistic sampling, 224 women volunteered to participate in the study. The aim and scope of the study was explained to the participants and a written informed consent was obtained from them. The study was approved by the Marmara University, School of Medicine, Ethics Committee with the protocol number 09.2017.381.

The data was collected through a questionnaire including "The Scale for Mother's identification of Safety Measures against Home Accidents for Children of 0-6 Years Age Group (MISMHA)". Turkish validity and reliability of the scale was done elsewhere (9) with a Cronbach Alpha value of 0.8205. This scale consists of 40 Likert type questions ( 34 positive, 6 negative statements). For the positive statements the scale was graded as follows: always, 5 points; often, 4 points; sometimes, 3 points; rarely, 2 points; never, 1 point. For the negative statements the grading 
system was reversed. Maximum scale score was 200 . The higher score represents a higher level of preventive measures against home accidents. The questionnaires were either given to the participants and filled by them or asked face to face by their request.

\subsection{Statistical analysis}

The data was analyzed with the Statistical Packages for the Social Sciences (SPSS) version 20.0 (IBM Corp.; Armonk, NY, USA). Normality of the distributions were tested with Kolmogorov Smirnov test. Since the distribution of all the numerical variables were not normal, we used MannWhitney $U$, Kruskal-Wallis and Spearman correlation tests for associations. For multivariate analyses, we made binary logistic regression models, taking the type of the accident as the dependent variable (dichotomized as having the accident and not having the accident), and other factors as independent variables (mother's age; mother's age at marriage; number of children living in the house; family type, mother's education level; mother's work status; family income; child's gender and age; birth order; MISMHA score; and taking specific education about home accidents). P-values less than 0.05 were considered significant.

\section{RESULTS}

From the three FHCs, 224 mothers participated in this study. Median age of the mothers (32 years) was lower than of the fathers ( 35 years). Median age at marriage and at first delivery for the mothers were 24 and 25 years respectively. On the other hand, 7 mothers (3.3\%) were married before the 18 years of age; and 2 (1\%) of them also had their first deliveries before 18 years of age. The sociodemographic characteristics of the participants are shown in Table 1 . We classified home accidents as falling (48.9\%), crash $(30.6 \%)$, burn $(9.2 \%)$, choking $(8.1 \%)$, cutting or piercing injury $(4.8 \%)$, poisoning (3.4\%), electric shock $(0.5 \%)$ and finger jam (36.6\%). The proportion of having any type of accident was $58.9 \%$.

Table 1. Socio-demographic characteristics of the study population.

\begin{tabular}{|c|c|c|c|}
\hline \begin{tabular}{|l|} 
Characteristics \\
\end{tabular} & $n^{*}$ & Mean & $S D^{* *}$ \\
\hline Mother's age (year) & 221 & 33 & \pm 6 \\
\hline Father's age (year) & 218 & 36 & \pm 7 \\
\hline Mother's age at marriage (year) & 213 & 24 & \pm 4 \\
\hline Mother's age at first delivery (year) & 209 & 26 & \pm 5 \\
\hline Caregiver's age (year) & 164 & 36 & \pm 11 \\
\hline Child's age (year) & 109 & 3 & \pm 2 \\
\hline \multirow[t]{2}{*}{ Family's income (Turkish Liras/month) } & 187 & 4120 & \pm 3296 \\
\hline & n* & Median & $I^{\prime Q R} R^{* * *}$ \\
\hline Child's birth order & 116 & 1 & $1-2$ \\
\hline Number of children living in the house & 219 & 2 & $1-2$ \\
\hline Number of persons living in the house & 220 & 4 & $3-5$ \\
\hline Number of the rooms at the house & 219 & 3 & $3-4$ \\
\hline
\end{tabular}

The majority (84.5\%) of the families in the study were large families; that is, they were living with some of their relatives other than spouses or children. Of the women, $67.2 \%$ had education level equal to or lower than high school; $5 \%$ were illiterate. Also, $20.1 \%$ of them had been educated about home accidents. Of the children, $57 \%$ were male; and $60.8 \%$ were the first child of the mother. The majority of the children (76.6\%) were given care primarily by their mothers and none of them by their fathers. Further information about the characteristics of the study population can be seen in table 2 .

In order to investigate the internal consistency of the MISMHA scale in our study population we checked the Cronbach Alpha value and found as 0.853 . Regarding the scale scores, we found no association between preventive measures against home accidents and family type, education level (both mother and father), work status (both father and mother), child's gender, child's birth order and the primary caregiver (Table 2). However, the scale scores were significantly higher among those who have been educated about home accidents (188.0; IQR: 177.0193.0) compared to those who haven't been (181.5; IQR: 169.5190.0) ( $p=0.013$ ) (Table 2). Also, we found a weak positive correlation between the scale score and family's monthly income ( $r=0.157, p=0.039)$; and a weak negative correlation between the scale score and child's age ( $r=-0.331, p=0.001)$. There was no correlation between the scale score and mother's, father's and caregiver's age; mother's age at marriage and at the first delivery; number of children living in the house; number of people living in the house; and number of rooms in the house.

Table 2. Socio-demographic characteristics of the study population by MISMHA scale scores.

\begin{tabular}{|c|c|c|c|c|c|c|}
\hline Variable & Categories & $n^{*}$ & $\begin{array}{l}\text { Valid } \\
\%\end{array}$ & $\begin{array}{l}\text { Score } \\
\text { (median) }\end{array}$ & IQR** & P value \\
\hline \multirow{2}{*}{ Family type } & Nuclear & 34 & 15.5 & 180.5 & $165.0-190.0$ & \multirow{2}{*}{$0.591^{a}$} \\
\hline & \begin{tabular}{|l|} 
Large \\
\end{tabular} & 185 & 84.5 & 184.0 & $172.0-192.0$ & \\
\hline \multirow{5}{*}{$\begin{array}{l}\text { Mother's } \\
\text { education } \\
\text { level }\end{array}$} & |lliterate & 11 & 5.0 & 185.0 & $172.0-194.0$ & \multirow{5}{*}{$0.098^{b}$} \\
\hline & $\begin{array}{l}\text { Primary- } \\
\text { secondary school }\end{array}$ & 63 & 28.6 & 183.5 & $172.0-193.0$ & \\
\hline & High school & 74 & 33.6 & 180.0 & $168.0-188.0$ & \\
\hline & University & 64 & 29.1 & 188.0 & $175.0-192.0$ & \\
\hline & Postgraduate & 8 & 3.6 & 176.0 & $155.0-186.0$ & \\
\hline \multirow{5}{*}{$\begin{array}{l}\text { Father's } \\
\text { education } \\
\text { level }\end{array}$} & Illiterate & 3 & 1.4 & 196.0 & 185.0-196.0 & \multirow{5}{*}{$0.277^{b}$} \\
\hline & $\begin{array}{l}\text { Primary- } \\
\text { secondary school }\end{array}$ & 66 & 30.3 & 180.0 & 190.0 & \\
\hline & \begin{tabular}{|l|} 
High school \\
\end{tabular} & 64 & 29.4 & 185.0 & $174.0-192.0$ & \\
\hline & University degree & 71 & 32.6 & 183.0 & 170.0-191.0 & \\
\hline & Postgraduate & 14 & 6.4 & 183.5 & $171.5-192.0$ & \\
\hline \multirow{2}{*}{$\begin{array}{l}\text { Mother's } \\
\text { work status }\end{array}$} & Employed & 88 & 40.4 & 186.0 & 174.0-192.0 & \multirow{2}{*}{$0.072^{\mathrm{a}}$} \\
\hline & Unemployed & 130 & 59.6 & 180.5 & $169.0-191.0$ & \\
\hline \multirow{2}{*}{$\begin{array}{l}\text { Father's } \\
\text { work status }\end{array}$} & Employed & 198 & 90.8 & 184.0 & $171.0-192.0$ & \multirow{2}{*}{$0.411^{\mathrm{a}}$} \\
\hline & Unemployed & 20 & 9.2 & 178.0 & $172.0-186.0$ & \\
\hline \multirow{2}{*}{$\begin{array}{l}\text { Educated } \\
\text { about home } \\
\text { accidents }\end{array}$} & Yes & 44 & 20.1 & 188.0 & $177.0-193.0$ & \multirow[b]{2}{*}{$0.013^{\mathrm{a}}$} \\
\hline & No & 175 & 79.9 & 181.5 & $169.5-190.0$ & \\
\hline \multirow{2}{*}{$\begin{array}{l}\text { Child's } \\
\text { gender }\end{array}$} & Female & 49 & 43.0 & 184.5 & $172.0-192.0$ & \multirow[b]{2}{*}{$0.061^{\mathrm{a}}$} \\
\hline & Male & 65 & 57.0 & 176.0 & $163.0-191.0$ & \\
\hline \multirow{2}{*}{ Birth order } & First & 73 & 60.8 & 178.0 & $165.0-189.0$ & \multirow{2}{*}{$0.194^{a}$} \\
\hline & Others & 47 & 39.2 & 183.5 & $172.5-192.0$ & \\
\hline \multirow{4}{*}{ Caregiver } & Mother & 128 & 76.6 & 181.5 & $169.0-190.5$ & \multirow{4}{*}{$0.279^{b}$} \\
\hline & Grandmother & 25 & 15.0 & 181.0 & $173.0-191.0$ & \\
\hline & Babysitter & 11 & 6.6 & 189.0 & $176.0-193.0$ & \\
\hline & Aunt & 3 & 1.8 & 194.0 & $174.0-195.0$ & \\
\hline \multicolumn{7}{|c|}{$\begin{array}{l}{ }^{*} n: \text { number of the participants; }{ }^{* *} \mid Q R: \text { Inter-quartile range } \\
\text { a: } p \text { values are derived from Mann-Whitney U tests; } b: p \text { values are derived } \\
\text { from Kruskal-Wallis tests }\end{array}$} \\
\hline
\end{tabular}


We also compared the scale scores of the mothers whose children have had a certain type of accident and who haven't had. For each type of the accident the scores were higher among those haven't had the accident than those who have had the accident; however, the difference was statistically significant only for crash $(p=0.033)$ (Table 3).

Table 3. MISMHA Scale scores by the type of the accident

\begin{tabular}{|c|c|c|c|c|c|c|}
\hline $\begin{array}{l}\text { Accident } \\
\text { type }\end{array}$ & Status & $n^{*}$ & $\begin{array}{l}\text { Valid } \\
\%\end{array}$ & $\begin{array}{l}\text { Score } \\
\text { (median) }\end{array}$ & IQR** & $\begin{array}{l}\mathbf{P} \\
\text { value } * * *\end{array}$ \\
\hline \multirow[t]{2}{*}{ Fall } & Yes & 107 & 48.9 & 180.0 & $\begin{array}{l}169.0- \\
190.0 \\
\end{array}$ & \multirow[t]{2}{*}{0.114} \\
\hline & No & 112 & 51.1 & 185.0 & $\begin{array}{l}173.0- \\
192.0 \\
\end{array}$ & \\
\hline \multirow[t]{2}{*}{ Crash } & Yes & 64 & 30.6 & 178.0 & $\begin{array}{l}167.0- \\
188.0\end{array}$ & \multirow[t]{2}{*}{0.033} \\
\hline & No & 145 & 69.4 & 185.0 & $\begin{array}{l}172.0- \\
192.0 \\
\end{array}$ & \\
\hline \multirow[t]{2}{*}{ Burn } & Yes & 19 & 9.2 & 174.0 & $\begin{array}{l}161.0- \\
191.0\end{array}$ & \multirow[t]{2}{*}{0.121} \\
\hline & No & 188 & 90.8 & 184.0 & $\begin{array}{l}172.0- \\
192.0\end{array}$ & \\
\hline \multirow[t]{2}{*}{ Chocking } & Yes & 17 & 8.1 & 175.0 & $\begin{array}{l}165.0- \\
187.0\end{array}$ & \multirow[t]{2}{*}{0.108} \\
\hline & No & 192 & 91.9 & 184.0 & $\begin{array}{l}172.0- \\
192.0\end{array}$ & \\
\hline \multirow{2}{*}{$\begin{array}{l}\text { Cutting or } \\
\text { piercing } \\
\text { injury }\end{array}$} & Yes & 10 & 4.8 & 173.0 & \begin{tabular}{|l}
$165.0-$ \\
189.0 \\
\end{tabular} & \multirow[t]{2}{*}{0.258} \\
\hline & No & 197 & 95.2 & 183.0 & $\begin{array}{l}172.0- \\
192.0\end{array}$ & \\
\hline \multirow[t]{2}{*}{ Poisoning } & Yes & 7 & 3.4 & 174.0 & $\begin{array}{l}146.0- \\
185.0\end{array}$ & \multirow[t]{2}{*}{0.205} \\
\hline & No & 200 & 96.6 & 183.0 & \begin{tabular}{|l}
$172.0-$ \\
192.0 \\
\end{tabular} & \\
\hline \multirow[t]{2}{*}{$\begin{array}{l}\text { Electric } \\
\text { shock }\end{array}$} & Yes & 1 & 0.5 & 183.0 & $\begin{array}{l}183.0- \\
183.0 \\
\end{array}$ & \multirow[t]{2}{*}{1.00} \\
\hline & No & 207 & 99.5 & 183.0 & $\begin{array}{l}171.0- \\
192.0\end{array}$ & \\
\hline \multirow[t]{2}{*}{$\begin{array}{l}\text { Finger } \\
\text { jam }\end{array}$} & Yes & 78 & 36.6 & 181.0 & $\begin{array}{l}170.0- \\
192.0\end{array}$ & \multirow[t]{2}{*}{0.843} \\
\hline & No & 135 & 63.4 & 184.0 & $\begin{array}{l}172.0- \\
191.0\end{array}$ & \\
\hline \multirow[t]{2}{*}{$\begin{array}{l}\text { Any } \\
\text { accident }\end{array}$} & Yes & 129 & 58.9 & 180.5 & \begin{tabular}{|l}
$173.0-$ \\
192.0 \\
\end{tabular} & \multirow[t]{2}{*}{0.313} \\
\hline & No & 90 & 41.1 & 180.5 & $\begin{array}{l}169.5- \\
191.5\end{array}$ & \\
\hline
\end{tabular}

We also found a trend between the age of the child and the type of the accident (Figure 1). As seen in the figure, the percentage of falls increases critically from age 1 to 2 , then follows a steady increase till its peak at age 5 . The crash accidents follow a pathway similar to falls; the percentage increases dramatically from age 1 to 2 ; then follows a steady increase and reaches its peak at age 3; after that it decreases slowly. Finger jam trend shows a stepped increment, it shows a dramatic increase from age 1 to 2 , then becomes steady for one year and increases again from age 3 to 4; after 4, it shows a small decrease. Burn accident follows a small decrease from age 1 to 4 and then increases dramatically to age 5. Cut/piercing injuries start at age 2 and follow a steady increase throughout the ages until 5. Choking follows a steady pathway until age 4 and the percentage decreases after that until age 5 . Poisoning and electric shock are rare accidents which are seen at age 4 and after.

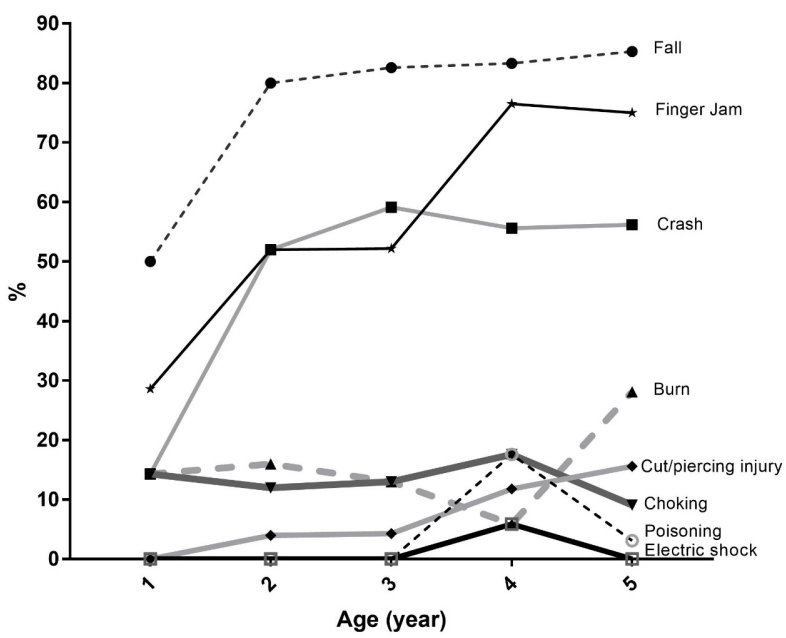

Figure 1. Percentage of children having different types of home accidents by their age.

In the last steps of the logistic regression models, we found that taking a specific education about home accidents is associated with lower rates of falling; being a girl is associated with lower rates of crash; and being young is associated with lower rates of finger jam (Table 4).

Table 4. Independent predictors of different types of accidents, binary logistic regression, last models.

\begin{tabular}{|l|l|l|l|l|l|}
\hline $\begin{array}{l}\text { Type } \\
\text { of the } \\
\text { accident }\end{array}$ & Variable & Categories & $\begin{array}{l}\text { Exp (B) } \\
\text { [OR]* }\end{array}$ & $95 \% \mathrm{Cl}^{* *}$ & $\begin{array}{l}\mathrm{P} \\
\text { value }\end{array}$ \\
\hline Falling & $\begin{array}{l}\text { Taking specific } \\
\text { education }\end{array}$ & $\begin{array}{l}\text { Yes } \\
\text { (reference } \\
\text { category) }\end{array}$ & 1 & & 0.017 \\
\cline { 3 - 5 } & No & 4.978 & $1.332-18.608$ & \\
\hline Crash & $\begin{array}{l}\text { Gender of the } \\
\text { child }\end{array}$ & $\begin{array}{l}\text { Girl } \\
\text { (reference } \\
\text { category) }\end{array}$ & 1 & & 0.041 \\
\cline { 2 - 5 } & Boy & 3.072 & $1.047-9.017$ & \\
\hline $\begin{array}{l}\text { Finger } \\
\text { jam }\end{array}$ & $\begin{array}{l}\text { Age of the } \\
\text { child (years) }\end{array}$ & $\begin{array}{l}\text { Continuous } \\
\text { variable }\end{array}$ & 0.567 & $0.374-0.859$ & 0.007 \\
\hline $\begin{array}{l}\text { *Exponentiation of the B coefficient or Odd Ratio [OR]; **Confidence } \\
\text { interval }\end{array}$
\end{tabular}




\section{DISCUSSION}

The first five years of human life are considered as a critical period that children are very active and try to discover and learn what is happening around them (10). This period is an important period for preventing home accidents and accident-related injuries and mortality. Our study helps to understand the factors associated with preventive measures against home accidents.

Our study population has higher socio-economic status compared to Turkey's average, with higher income, educational status, age at marriage and age at first delivery. Such as the rate of illiteracy in our study population (5\%) was lower than Turkey's average (9.0\%) (11); mother's median age at marriage (24 years) was older than Turkey's national (21 years) and Istanbul's (21.4 years) median age at marriage. Similarly, mother's median age at first delivery in our study population (25 years) was older than Turkey's national (22.9 years) and Istanbul's (24.6 years) median age at marriage (12, 13).

The most significant finding of our study was that the women who were specifically educated about home accidents were taking more preventive measures. This finding is consistent with previous studies. In two studies conducted by Turan et al. (14) and Çınar (15) to find out the effect of educating mothers about home accidents, demonstrated that the knowledge level of the mothers were significantly higher after the education than before the education. King et al. (16) also conducted a study to prevent home accidents in childhood by visiting homes and providing education; the study showed that after the education in the vast majority $(63 \%)$ of the participants there was an improvement in knowledge, attitude and practices about home accidents. Systematic reviews $(17,18,19,20)$ show that one of the most effective strategies to prevent home accidents is educating parents and children to make behavior change and promote safety apparatus in houses. However, having knowledge does not always make people apply it in practice. On the other hand, in this study, we investigated the specific education with a question "have you ever taken a specific education about home accidents". Therefore, it doesn't provide a comprehensive information about the type and content of the education. Further qualitative and quantitative studies may explore this information.

In our study we found no association between safety measures and mother's education level. This may be because of the lack of specific courses about home accidents within the national educational curricula in Turkey. Although there are some chapters regarding the first aid after some types of accidents in the lecture of "Health Knowledge and Traffic Culture" in national high school curriculum, there is no specific and comprehensive education about home accidents (21).

We found a weak association between taking preventive actions and family's income; since higher income level can be a reflection of general higher socio-economic status, these families might be more aware of home accidents; or for them, taking preventive measures might be more affordable (22).

We also found a weak negative correlation between the scale score and child's age; on the other hand, we found that frequency of home accidents increase with age. This might be explained by the tendency of mothers to take less preventive measures when their children have grown. However, we cannot make a temporal inference from these associations. Since we don't know whether the accidents are more frequent because mothers take less preventive measures, or because mothers take less preventive measures the accidents happen more frequently.

The trends we found between the age of child and the type of the accident can be explained by the neurodevelopmental stages of the child (23). As the children develop more motor skills, they tend to explore their surrounding environments and thus the frequency of most accident types increases. The dramatic increase of falling, crash and finger jam from age 1 to age 2 can also be explained by the neurodevelopmental process of the child; after the first year of age when they start to walk they might face more accidents. Particularly serious accidents, such as poisoning, electric shock start at older ages when they gain more control over their extremities and acquire ability to grasp objects; also, as their height increase they might be able to reach the objects in higher places such as shelves, drawers, electric sockets (24).

In a qualitative study conducted with mothers in Wales (25) it was found that fathers also have a role in prevention of home accidents and related injuries. As our study was conducted only among mothers, there is not adequate information about fathers' roles. Therefore in the future, a study that includes the fathers will give a more comprehensive information.

Also, since this study was conducted among the mothers who referred to family health centers there might be a referral filter bias. These mothers may be more aware of health related issues compared to those who didn't refer to the health centers; therefore, the status of taking preventive measures among those who didn't refer to health centers may be worse. Furthermore, the participants might have reported preventive measures more than they actually do. This can be an outcome of social desirability bias. Therefore, the scale scores we have found in this study might be an over-estimation of true preventive measures. Moreover, our study population had a higher socio-economic status than Turkey's average; therefore, the general situation regarding preventive measures taken by parents in Turkey probably is worse than our findings.

\section{CONCLUSION}

We concluded that, not the formal education but taking a specific education about home accidents increase preventive measures against home accidents. Therefore, a structured education specifically addresses home accidents is very important to increase the quantity and quality of preventive 
measures against home accidents (26). This education should comprehensively cover the most common (i.e. falls, crashes) and serious (i.e. burning, choking) home accidents considering the age of the child; and should be interactive and practice-based in addition to theoretical knowledge. This education may target current mothers, teenagers, pregnant women etc. to have a short-term outcome; or can be integrated to curriculum of secondary schools or universities in a continuous fashion for a sustainable long-term outcome. We didn't investigate the source of information about home accidents in our study, however, previous studies $(27,28)$ found mass media as an important source of information; therefore mass media can also be used in raising awareness about home accidents.

Conflict of Interest and Financial Disclosure: We declare that this study has not been funded by any means and we have no conflict of interest to disclose.

\section{REFERENCES}

[1] Özmen D, Ergin D, Şen N, Çetinkaya AÇ. To identify safety measures of mothers of children aged between 0 and 6 years against home accidents. Aile Toplum 2007;3:13-20.

[2] Altundağ S, Öztürk MC. Ev kazaları nedeniyle hastaneye gelen 3-6 yaş grubu çocuklardaki kaza türleri ve bunu etkileyen etmenler. Çocuk Forum Derg 2004;5(Turkish).

[3] Hamzaoglu O, Özkan Ö, Janson S. Incidence and causes of home accidents at Ankara Çigiltepe apartments in Turkey. Accid Anal Prev 2002;34(1)(Turkish).

[4] Kendrick D, Ablewhite J, Achana F, Benford P, Clacy R, Coffey F, Cooper N, Coupland C, Deave T, Goodenough T, Hawkins A, Hayes M, Hindmarch P, Hubbard S, Kay B, Kumar A, Majsak-Newman G, McColl E, McDaid L, Miller P, Mulvaney C, Peel I, Pitchforth E, Reading R, Saramago P, Stewart J, Sutton A, Timblin C, Towner E, Watson MC, Wynn P, Young B, Zou K. Keeping Children Safe: a multicentre programme of research to increase the evidence base for preventing unintentional injuries in the home in the under-fives. Chapter 1, Introduction to the Keeping Children Safe programme of research (Programme Grants for Applied Research, No. 5.14). Southampton: NIHR Journals Library; 2017.p.1 Available from: https://www.ncbi.nlm.nih.gov/books/NBK447051/

[5] Çınar ND, Görak G. Mother's role in preventing childhood home accidents. Revista Brasileira em Promoção da Saúde. 2007;20(4):238-242.

[6] Thanh NX, Hang HM, Chuc NT, Lindholm L. The economic burden of unintentional injuries: a community-based cost analysis in Bavi, Vietnam. Scand J Public Health Suppl. 2003;62:45-51.

[7] Alptekin F, Uskun E, Kisioglu AN, Ozturk M. Unintentional non-fatal home related injuries in Central Anatolia, Turkey: frequencies, characteristics, and outcomes. Injury. 2008;39:535-546.

[8] Malta DC, Mascarenhas MD, Silva MM, Carvalho MG, Barufaldi LA, Avanci JQ, Bernal RT. The occurrence of external causes in childhood in emergency care: epidemiological aspects, Brazil, 2014. Cien Saude Colet. 2016;21(12):3729-3744.
[9] Çınar ND, Görak G. 0-6 yaş çocuklarda annenin ev kazalarına yönelik güvenlik önlemlerini tanılama ölçeğinin geliştirilmesi, geçerlik ve güvenirlik çalışması. Çocuk Forumu (Turkish).

[10] Wong DL, Eaton MH, Winkelstein ML, Wilson D, Ahmann E, Thomas P. Nursing care of infants and children, health promotion of the preschooler and family (6th ed.). Mosby, New York, 1999.p.613-615.

[11] Turkish Statistical Institute. Women in Statistics, 2016, Available from: http://www.turkstat.gov.tr/PreHaberBultenleri. do?id $=24643$

[12] Hacettepe University Institute of Population Studies, T.R. Ministry of Development, T.R. Ministry of Health, and ICF. Turkey Demographic and Health Survey 2013. Ankara, Turkey: Hacettepe University Institute of Population Studies, Ministry of Health, Ministry of Development. 2014.p70;p107-109. Available at http://dhsprogram.com/pubs/pdf/FR352/FR352. pdf.

[13] Turkish Statistical Institute. Marriage and Divorce Statistics, 2012, Available from: http://www.turkstat.gov.tr/ PreHaberBultenleri.do?id=13469

[14] Turan T, Dündar SA, Yorgancı M, Yıldırım Z. The prevention of home accidents among children aged 0-6 years. Ulus Travma Acil Cerrahi Derg 2010;16(6):552-557.

[15] Çınar N. 0-6 yaş çocuklarda annenin ev kazalarına yönelik güvenlik önlemlerini tanılama ölçeğinin geliştirilmesi ve çocuktaki kazaları önlemede annelere verilen eğitimin etkisi. İstanbul Üniversitesi Sağlık Bilimleri Enstitüsü, Doktora Tezi. (Turkish).

[16] King WJ, LeBlanc JC, Barrowman NJ, Klassen TP, BernardBonnin AC, Robitaille Y, Tenenbein M, Pless I. Long term effects of a home visit to prevent childhood injury: three year follow up of a randomized trial. Inj Prev 2005;11:106-109.

[17] Dowswell T, Towner EM, Simpson G, Jarvis SN. Preventing childhood unintentional injuries-what works? A literature review. Inj Prev 1996;2(2):140-149.

[18] Kendrick D, Smith S, Sutton A, Watson M, Coupland C, Mulvaney C, Mason-Jones A. Effect of education and safety equipment on poisoning prevention practices and poisoning: systematic review, meta-analysis and meta-regression. Arch Dis Child 2008;93(7):599-608.

[19] Kendrick D, Barlow J, Hampshire A, Stewart-Brown S, Polnay L. Parenting interventions and the prevention of unintentional injuries in childhood: systematic review and meta-analysis. Child Care Health Dev 2008;34(5):682-695.

[20] Ehiri JE, Ejere HO, Magnussen L, Emusu D, King W, Osberg SJ. Interventions for promoting booster seat use in four to eight year olds travelling in motor vehicles. Cochrane Database Syst Rev 2006;(1):CD004334.

[21] Alper B, Can E, Demirhan F, Güleç G, Yılmaz M, Kalın YG. İlk yardımla ilgili temel bilgiler. Sağlık Bilgisi ve Trafik Kültürü, Ders Kitabı 9. Yılmaz F, Turan S, editors. Milli Eğitim Bakanlığı devlet kitapları; (Turkish).

[22] Büyük E, Çavuşoğlu F, Teker E, Defining the security measures taken by mothers with zero to six years old children against home accidents. J DU Health Sci Inst 2015;5(3):17-22

[23] Ciampo LA, Ciampo IRL, Unintentional Injuries among Children: An Observational Study in a Basic Health Unit in Ribeirão Preto, Brazil. American Journal of Pediatrics 2016;2(5):19-22

[24] Gärling A, Gärling T. The Ability of Mothers of Young Children to Anticipate Potential Home Accidents. Children's Environments Quarterly 1991;1:24-30. 
[25] Khanom A, Hill RA, Brophy S, Morgan K, Rapport F, Lyons R. Mothers' perspectives on the delivery of childhood injury messages: A qualitative study from the growing up in Wales, environments for healthy living study (EHL). BMC Public Health 2013;13:806.

[26] Çapık C, Gürol AP. Effect of Education on Mothers' Capability of Identification of Safety Precautions of Home Accidents. Kafkas J Med Sci 2014;4(3):87-94
[27] Megahed MA, Khalil NA, Ibrahem RA, El Disoki RS. Knowledge, attitude and practice of rural mothers towards home injuries among children under 5 years of age in Menouf District Menoufia Governorate, Egypt. Menoufia Med J 2016;29:10331039.

[28] Suguna TC. Women's awareness about domestic accidents among toddlers. IJDR 2015; 5(3):3729-3733. 